\title{
Tradisi Sedekah Obat Masyarakat Desa Jermun Kecamatan Pampangan Kabupaten Ogan Komering Ilir
}

\author{
Ahmad Gurdachi' ${ }^{1}$, Armys Dwi Prasetyo² \\ ${ }^{1,2}$ Fakultas Adab dan Ilmu Budaya, UIN Sunan Kalijaga Yogyakarta \\ email: ahmadgurdachiaisy1996@gmail.com
}

\begin{abstract}
Abstrak
Artikel ini bertujuan untuk mendeskripsikan tradisi Sedekah Obat yang ada di Jermun. Pendekatan yang digunakan dalam penelitian ini adalah pendekatan antropologi. Data dalam penelitian ini adalah data kualitatif yang bersumber dari data primer dan sekunder. Sumber data primer berasal dari pemangku adat, pemangku agama, pemerintah setempat, serta masyarakat yang ada kaitannya dengan penelitian ini. Sedangkan sumber data sekunder dikumpulkan dari berbagai literatur, seperti buku, jurnal, yang berhubungan dengan tema yang dibahas. Teknik pengumpulan data dengan observasi, interview dan dokumentasi. Dalam melakukan analisis, peneliti menggunakan teknik analisis kualitatif yaitu analisa terhadap data-data yang bersifat kualitatif dengan mengumpulkan data, mengedit data yang telah terkumpul dan mengklasifikasikan jawabanjawaban para responden, setelah itu barulah melakukan intepretasi (penafsiran) data yang sudah terkumpul melalui pokok-pokok bahasan. Tradisi Sedekah Obat dilakukan pada satu tahun sekali pada bulan Muharram, diadakannya tradisi ini karena dahulu terjadi malapetaka yang menimpa masyarakat di Desa Jermun. Hal yang terpenting dari pelaksanaan tradisi Sedekah Obat ini agar Desa Jermun selalu diberi keberkahan, kesehatan dan dijauhkan dari segala malapetaka sekaligus bentuk rasa syukur kepada sang pencipta. Dari tradisi Sedekah Obat menghasilkan dua nilai yaitu nilai solidaritas dan nilai agama.
\end{abstract}

Kata Kunci: Tradisi Sedekah Obat, Sejarah, Nilai dan Adat Istiadat.

\begin{abstract}
This article heads for describing give a religious meal tradition of medicine on Jermun village. This article investigated for history of give a religious meal tradition of medicine, goals, processions, along with the value which be found in this tradition, the methode is using in this article is anthropology approach. The value in this article is qualitative value. Which be based onj from primary velue and secondary value. Primary value taken from funchtionary of tradition. Leader of religion, and the government at the area. Along with society which connecting with this research. While the value of secondary taken from many of literature, like a book, journal, which related in this article's title. Technique aggregation of sheaf with observation, interview, and documentation. For doing analysis, researcher take e technique of qualitative analysis whice to anlyze about the sheafs has the quality for qualitative with collecting value, editing value, which collected it and to clarify the aswers of responden. And after that, doing interpretation value which collected from then mains of article. This tradition did once in a year on Muharram, this tardition was held because was happened misfortune which befiled to society long time ago in Jermun village. Let the Jermun village always gived blessing from God Allah Swt, healthy and kept away from any misfortune all at once for gratitue with God. This tradition produce two goals are solidarity and religion of value.
\end{abstract}




\section{A. PENDAHULUAN}

Kebudayaan merupakan keseluruhan sistem gagasan, tindakan dan hasil karya manusia dalam rangka kehidupan masyarakat yang dijadikan milik dari manusia dengan belajar. ${ }^{1}$ Menurut E.B. Tylor, bahwa kebudayaan adalah keseluruhan kompleks, yang di dalamnya terkadang ilmu pengetahuan, kepercayaan, kesenian, moral Islam, hukum, adat-istiadat, dan kemampuan yang lain serta kebiasaan yang didapat oleh manusia sebagai anggota masyarakat. ${ }^{2}$ Kebudayaan yang ada di dunia dan masyarakat tidak terlepas dari beberapa unsur-unsur kebudayaan, dan yang sering dikenal dengan isi pokok kebudayaan yaitu: 1. Unsur Bahasa 2. Sistem Pengetahuan 3. Organisasi Sosial 4. Sistem Peralatan dan Teknologi 5. Sistem Mata Pencaharian Hidup 6. Sistem Religi 7. Sistem Seni. ${ }^{3}$

Menurut Kroeber dan Kluckhon kebudayaan terdiri atas berbagai pola, bertingkah laku mantap, pikiran, perasaan dan reaksi yang diperoleh, dan terutama yang diturunkan oleh simbol-simbol yang menyusun pencampaian secara tersendiri dari kelompok-kelompok manusia. ${ }^{4}$ Kebudayaan tidak terlepas dari kehidupan kelompok, karena kebudayaan merupakan unsur pengorganisasian antara individu dan membentuknya menjadi salah satu kelompok, setiap kebudayaan mempunyai ciri khas, karena merupakan penyesuaian manusia kepada lingkungan hidupnya, serta usahanya dalam mengelompokkan, yang berarti dalam organisasinya untuk mempertahankan kelangsungan hidupnya sesuai dengan keadaaan menurut pengalamannya. ${ }^{5}$

Kebudayaan dalam hal ini, dapat dilihat sebagai "mekanisme kontrol" bagi kelakuan daan tindakan-tindakan sosial manusia, atau sebagai "pola-pola bagi kelakuan manusia". Sementara itu, masyarakat secara sederhana, dapat didefinisikan sebagai suatu sistem yang terdiri atas peranan-peranan dan kelompok-kelompok yang saling berkaitan dan saling mempengaruhi, yang di dalam tindakan-tindakan dan tingkah laku sosial manusia diwujudkan. Dalam masyarakat manusia mengembangkan kebudayaannya. ${ }^{6}$

Di Indonesia sendiri terdiri dari beraneka ragam kebudayaan dan adat istiadat yang telah ada sejak kehidupan manusia purba di zaman prasejarah. Pada zaman itu masyarakat memiliki sistem nilai, nilai-nilai budaya termasuk budaya spiritual bangsa falsafah negara yaitu Pancasila

\footnotetext{
${ }^{1}$ Koentjaraningrat, Pengantar Ilmu Antropologi (Jakarta: PT Rineka Cipta, 2003), hal. 180.

${ }^{2}$ Harsojo, Pengantar Antropologi (Bandung: PT Rina Cipta, 1998), hal. 92.

${ }^{3}$ Ibid., hal. 204.

${ }^{4}$ M. Munandar Sulaeman, Ilmu Budaya Dasar (Bandung: Rafika Aitama, 2012), hal. 35.

5 Saudi Berlian, Mengenal Seni Budaya Ogan Komering Ilir (Palembang: Pemerintah Kabupaten Oki,

${ }^{6}$ M. Munandar Sulaeman, Ilmu Sosial Dasar: Teori dan Konsep Ilmu Sosial (Bandung: Rafika Aditama,
} 2003), hal. 18. 2011), hal. 7-8. 
terkandung adanya motivasi bagi bangsa Indonesia untuk menggali serta mengamalkan nilainilai yang dianggap luhur. ${ }^{7}$ Di provinsi Sumatera Selatan khususnya yang dikenal dahulu dengan kerajaan Sriwijaya, terdapat banyak sekali peninggalan kebudayaan yang beraneka ragam bentuknya dan menjadi ciri khas bagi daerah setempat. Ada yang berbentuk nyata seperti: seni, peninggalan-peninggalan sejarah berupa candi, arca, prasasti dan lain-lain. Ada juga yang berbentuk kepercayaan terhadap sesuatu seperti benda-benda mati, makhluk hidup dan upacara-upacara adat tradisiaonal.

Di Desa Jermun Kecamatan Pampangan Kabupaten Ogan Komering Ilir, yang merupakan bagian dari Provinsi Sumatera Selatan mempunyai kebudayaan yang berupa upacara adat Sedekah Obat. Sedekah Obat merupakan tradisi pembersihan dusun sekaligus bentuk rasa syukur kepada Allah SWT atas nikmat kesehatan dan rezeki yang telah diberikannya. Tradisi Obat merupakan hasil dari peninggalan nenek moyang pada zaman terdahulu yang telah berlangsung secara turun-menurun dan terus dilestarikan sampai sekarang. Tradisi Sedekah Obat hanya berlangsung satu tahun sekali pada bulan Muharam. Tradisi ini terbilang unik dengan tradisi sedekah lainnya, terlihat dari segi pelaksanaan ritualnya yang berbeda dari tradisi sedekah di daerah-daerah tertentu khususnya di kawasan Sumatera Selatan.

Berkenaan dengan adanya keunikan yang terdapat dalam tradisi Sedekah Obat di Desa Jermun, maka dari latar belakang yang telah dijelaskan, penulis tertarik ingin meneliti dan mengkaji serta mempelajari lebih jauh karena adat ini masih tetap dilestarikan dan dijalankan oleh masyarakat Desa Jermun. Maka disini penulis memfokuskan dengan rumusan masalah sebagai titik fokus yaitu untuk mengetahui sejarah Tradisi Sedekah Obat di Desa Jermun, bagaimana proses berlangsungnya pelaksaan tradisi serta nilai-nilai yang dihasilkan dari Tradisi Sedekah Obat tersebut.

\section{B. TINJAUAN PUSTAKA}

Tinjauan pustaka merupakan unsur penting dari penelitian, karena berfungsi untuk menjelaskan posisi masalah yang akan diteliti di antara penelitian yang pernah dilakukan penelitian lain dengan maksud untuk menghindari terjadinya duplikasi (plagiasi) penelitian. ${ }^{8}$

Berapa kajian awal seperti yang ditulis oleh Widiawati, membahas tentang Upacara Adat Sedekah Pedusunan yang meliputi sejarah, proses penyelenggaraan dan unsur-unsur

\footnotetext{
${ }^{7}$ Gendro Nurhadi, Pengkajian Nilai-Nilai Luhur Budaya Spiritual Bangsa (Jakarta: Depdikbud, 1998), hal. $2-3$.

${ }^{8}$ Tim Penyusun, Pedoman Penulisan Skripsi Fakultas Adab dan Humaniora (Palembang: Fakultas Adab dan Humaniora Institut Agama Islam Negeri Raden Fatah Palembang, 2013), hal. 19.
} 
Islam yang terkandung di dalam Upacara Adat Sedekah Bedusun. ${ }^{9}$ Isi nya menjelaskan bahwa Upacara Adat Sedekah Pedusunan merupakan suatu adat atau tradisi turun temurun, yang diadakan untuk mengungkapkan rasa syukur atas selesai dan berhasilnya panen padi.

Penelitian yang dilakukan oleh Supriyadi tentang Sejarah Perkembangan Sedekah Turun Benih dan fungsi Tradisi Sedekah Turun Benih bagi Jamaah Baratib Al-Qadiriyah. ${ }^{10}$ Hasil temuan pada penelitian ini bahwa fungsi diadakannya tradisi sedekah turun benih. Pertama, bersyukur kepada Allah SWT. yang telah memberikan kesempatan bertemu dengan musim padi tahun tersebut. kedua, berdoa kepada Allah SWT agar apa yang ditanam mendapatkan hasil yang melimpah dan terhindar dari hama (penyakit) yang menyerang tanaman. ${ }^{11}$

Selanjutnya penelitian tentang "Makna Sedekah Pagi dan Petang Bagi Masyarakat Suku Rambang", yang ditulis oleh Nila Kisnawati, yang membahas tentang proses pelaksanaan sedekah pagi dan petang, proses Asimilasi terhadap makna sedekah, dan pandangan Islam terhadap Upacara pelaksanaan sedekah pagi dan petang masyarakat Suku Rambang. ${ }^{12}$

Kemudian penelitian yang dilakukan oleh Wulandari membahas tentang Sejarah Tradisi Krama Wali, Proses Pelaksanaan Tradisi dan Makna Simbol yang terkandung dalam Tradisi Krama Wali. ${ }^{13}$ Hasil temuan dalam skripsi ini yaitu dalam pelaksanaan dan peralatan yang disiapkan memiliki makna masing-masing.

Dari beberapa hasil penelitian di atas, ternyata belum ada yang mengangkat tentang "Tradisi Sedekah Obat Masyarakat Desa Jermun Kecamatan Pampangan kabupaten Ogan Komering Ilir, oleh karena itu dalam penelitian ini, penulis ingin membahas lebih mendalam tentang Tradisi Sedekah Obat di Desa Jermun tersebut. Penelitian ini penting dilakukan guna memberikan informasi tentang Sedekah Obat terkait penemuan baru yang ditemukan oleh penulis.

9 Widiawati, "Unsur-Unsur Islam Dalam Upacara Adat Sedekah Pedusunan Di Desa Gaung Asam Kecamatan Lembak Kabupaten Muara Enim” (Skripsi, Institut Agama Islam Negeri Raden Fatah Palembang, 2012), hal. 17.

${ }^{10}$ Supriyadi, “Tradisi Sedekah Turun Benih Bagi Jamaeeah Baratib Al-Qadiriyah Di Kelurahan Ngulak I Kecamatan Sanga Desa Kabupaten Musi Banyuasin (Tinjauan Historis)" (Skripsi, Institut Agama Islam Negeri Raden Fatah Palembang, 2008), hal. 5.

${ }^{11}$ Ibid., hal. 59.

${ }^{12}$ Nila Krisnawati, "Makna Sedekah Pagi Dan Petang Bagi Masyarakat Suku Rambang” (Skripsi, Institut Agama Islam Negeri Raden Fatah Palembang, 2003), hal. 8.

${ }^{13}$ Wulandari, "Makna Simbol Krama Wali Dalam Adat Pernikahan Di Desa Karang Anyar Kecamatan Lawang Wetan Kabupaten Musi Banyuasin” (Skripsi, Institut Agama Islam Negeri Raden Fatah Palembang, 2003), hal. 10. 


\section{METODE PENELITIAN}

Metode adalah suatu cara atau teknik untuk mencari suatu kebenaran. Penelitian adalah suatu proses pengumpulan dan analisis data yang dilakukan secara sistematis, untuk mencapai tujuan-tujuan tertentu. Pengumpulan dan analisis data dilakukan secara ilmiah, baik bersifat kuantitatif maupun kualitatif, eksperimental maupun non eksperimental, interaktif maupun non interaktif. ${ }^{14}$ Metode penelitian ialah suatu pengkajian dalam mempelajari peraturan-peraturan yang terdapat dalam penelitian. ${ }^{15}$

Dalam penelitian ini, penulis menggunakan metode pendekatan Antropologi. Digunakan pendekatan antropologi, karena kajian antropologi mempelajari beraneka ragam masyarakat dan lingkungan, penggunaan pendekatan antropologi dalam tulisan ini dimaksudkan untuk mempelajari beraneka ragam manusia dan kebudayaanya. Dengan menggunakan pendekatan ini penulis dapat mendeskripsikan secara jelas mengenai sosial budaya pada masyarakat Desa Jermun melalui tradisi Sedekah Obat. Pendekatan antropologi ini nanti juga diklasifikasikan menjadi pendekatan etnografi. Etnografi merupakan strategi penelitian ilmiah yang sering digunakan dalam ilmu sosial, terutama dalam antropologi dan beberapa cabang sosiologi, juga dikenal sebagai bagian dari ilmu sejarah yang mempelajari masyarakat, kelompok etnis, dan informasi etnis lainnya, etnogenesis, komposisi, perpindahan tempat tinggal, karakteristik kesejahteraan sosial, juga budaya material dan spiritual mereka. Etnografi sering diterapkan untuk mengumpul data empiris tentang masyarakat dan budaya manusia. Pengumpulan data biasanya dilakukan melalui pengamatan partisipan, wawancara, kuesioner, dan lain-lain. Ilmu ini bertujuan untuk menjelaskan keadaan masyarakat yang dipelajari.

Hal ini sesuai dengan metode yang dilakukan oleh peneliti yaitu dengan menggunakan metode penelitian kualitatif yang mana penulis dalam menggali dan mengumpulkan data menggunakan pengamatan langsung, wawancara dan lain-lain yang berkaitan dengan pendekatan etnografi serta mempelajari suatu budaya dalam masyarakat yang berkaitan dengan pendekatan antropologi budaya.

\footnotetext{
${ }^{14}$ Nana Syaodih Sukmadinata, Metode Penelitian Pendidikan (Bandung: Rosdakarya, 2005), hal. 5.

${ }^{15}$ Helen Sabera Adib, Metodologi Penelitian (Palembang: Noer Fikri, 2016), hal. 2.
} 


\section{HASIL DAN PEMBAHASAN}

\section{Sejarah Tradisi Sedekah Obat}

Tradisi Sedekah Obat sudah dilakukan sejak nenek moyang zaman dahulu yang masih tetap dilakukan secara turun temurun sampai sekarang. Oleh karena itu, tradisi tersebut tidak bisa dihilangkan begitu saja dan tetap dilaksanakan menurut adat yang berlaku dalam masyarakat. Upacara adat Sedekah Obat ini merupakan suatu kegiatan yang dilakukan berdasarkan budaya dan aturan-aturan yang sudah ditetapkan oleh masyarakat, karena kebudayaan itu sendiri hasil dari suatu proses yang panjang dengan melalui sejarah masa lalu. Penamaan tradisi Sedekah Obat sendiri sudah ada sejak zaman nenek moyang dulu. Sedekah Obat ini dilakukan agar Desa Jermun aman, tenteram dan terhindar dari malapetaka seperti, banjir, gangguan makhluk halus, wabah penyakit dan perampokan. Dalam sejarahnya pada zaman dahulu di Desa Jermun banyak sekali terjadi kejadian-kejadian buruk seperti, banjir, penyakit, gangguan makhluk halus, kemudian banyak terjadi perampokan yang meresahkan masyarakat. Oleh karena itu, nenek moyang terdahulu mengajak masyarakat untuk mengadakan Sedekah Obat dengan berdoa supaya tidak terjadi lagi malapetaka atau kejadiaan kejadian buruk di dusun mereka. ${ }^{16}$

Pada awal sejarah pelaksanaannya, Tradisi Sedekah Obat diadakan tujuh hari berturut-turut. Namun dengan perkembangan zaman akhirnya tradisi Sedekah Obat diringkas menjadi satu hari, menurut ketua adat sendiri menerangkan bahwa alasan mereka mempersingkat pelaksanaan tradisi tersebut adalah agar tidak mengganggu pekerjaan masyarakat hingga akhirnya tradisi ini disingkat selesai dalam satu hari. Tradisi Sedekah Obat hingga saat ini tetap dilestarikan hingga sekarang dilakukan satu tahun sekali.

\section{Tujuan Tradisi Sedekah Obat}

Pada masa peralihan antara satu tingkat kehidupan ke tingkat berikutnya biasanya diadakan pesta atau upacara dan sifatnya universal. Dalam berbagai kebudayaan ada anggapan bahwa masa peralihan merupakan saat-saat yang penuh bahaya baik nyata maupun gaib, karena itu upacara-upacara daur hidup seringkali mengandung unsur penolak bahaya gaib. ${ }^{17}$ Dalam kaitannya dengan sistem keyakinan, kekhawatiran yang mereka rasakan, mereka hubungkan dengan kekuasaan Tuhan dan kekuatan-kekuatan gaib, sehingga mereka

\footnotetext{
${ }^{16}$ Wawancara pribadi dengan Ibu Solbiah (Ketua Adat Desa Jermun), Pada tanggal 27-09-2018.

${ }^{17}$ Koentjaraningrat, Pengantar Antropologi II : Pokok-Pokok Etnografi (Jakarta: Rineka Cipta, 1997), hal. 92.
} 
Tamaddun: Jurnal Kebudayaan dan Sastra Islam, Vol. 20 No. 2, 2020 |

menyelenggarakan upacara daur hidup untuk meminta keselamatan. Mereka menyelenggarakan upacara-upacara sebagaimana yang sudah diatur oleh adat dan sistem kepercayaan mereka. Selain itu, penyelenggaraan upacara-upacara itu pun dianggap sebagai wujud bakti mereka kepada Tuhan. ${ }^{18}$

Di dalam kepercayaan dan keyakinan masyarakat Desa Jermun, dilakukannya tradisi Sedekah Obat adalah upaya berdoa dengan tujuan untuk menolak bala, dengan harapan masyarakat agar diberi keselamatan diri oleh Allah Swt supaya tidak terjadi lagi malapetaka atau kejadiaan kejadian buruk, ketua adat percaya bahwa apabila tradisi sedekah ini tidak dilaksanakan, Desa Jermun akan mendapatkan bencana, menurutnya tadisi Sedekah Obat harus dilaksanakan jika tidak malapetaka akan terjadi lagi. Selain itu, sedekah ini dilakukan sebagai bentuk rasa syukur warga akan rezeki yang telah dilimpahkan oleh Allah kepada masyarakat, meminta bimbingan kepada Allah Swt agar hari ini lebih baik dari hari yang lalu dengan cara berdoa bersama-sama di rumah ketua adat. ${ }^{19}$

\section{Proses Pelaksanaan Tradisi Sedekah Obat}

Sistem upacara keagamaan, melaksanakan dan melambangkan konsep-konsep yang terkandung dalam sistem kepercayaan. Seluruh sistem upacara itu terdiri dari aneka macam upacara yang besifat harian, musiman atau kadangkala. Masing-masing upacara terdiri dari kombinasi dari berbagai macam unsur upacara, misalnya: berdoa, bersujud, bersaji, berkorban, makan bersama, menari dan menyanyi. ${ }^{20}$ Dalam sistem upacara keagamaan tersebut secara khusus mengandung empat aspek yang menjadi perhatian khusus dari para ahli antropologi ialah: 1. Tempat upacara keagamaan dilakukan; 2. Saat-saat upacara keagamaan dijalankan; 3. Benda-benda dan alat upacara; 4. Orang-orang yang melakukan dan memimpin upacara. Menurut ahli antropologi bahwa dalam sistem upacara keagamaan secara khusus mengandung empat unsur yaitu tempat upacara dilakukan, waktu upacara dilakukan, bendabenda dan alat upacara dan orang-orang yang melakukan dan memimpin upacara. ${ }^{21}$ Tradisi keagamaan Sedekah Obat rutin dilakukan setiap tahun di bulan Muharam. Dalam melaksanakan upacara adat Sedekah Obat tentunya melalui proses yang terbagi dalam beberapa tahap. Dalam penelitian ini, penulis menemukan tiga tahapan berlangsungnya Tradisi Sedekah Obat yaitu tahap persiapan, tahap pelaksanaan, dan tahap akhir pelaksanaan ritual:

18 Ahmad Yunus, dkk., Arti dan Fungsi Upacara Daur Hidup pada Masyarakat Betawi (Jakarta: Depertemen Pendidikan dan Kebudayaan, 1993), hal. 62.

${ }^{19}$ Wawancara pribadi dengan Ibu Solbiah (Ketua Adat Desa Jermun), Pada tanggal 27-09-2018.

${ }^{20}$ Koentjaraningrat, Kebudayaan, Mentalitet Dan Pembangunan (Jakarta: Gramedia, 1974), hal. 139-140.

${ }^{21}$ Koentjaraningrat, Pengantar Antropologi II : Pokok-Pokok Etnografi, hal. 177-178. 


\section{a. Tahap persiapan.}

Sebelum upacara tradisi Sedekah Obat dilaksanakan, diperlukan persiapan dan tahaptahap mengenai beberapa masalah pelaksanaan Sedekah Obat yaitu mengenai adanya tempat pelaksanaan, saat-saat (waktu) berlangsungnya upacara, benda-benda sakral yang wajib digunakan dalam pelaksanaan upacara dan orang yang memimpin serta mendukung pelaksanaan upacara. Penulis menyimpulkan dua bagian hal terpenting sebagai tahap dalam persiapan tradisi Sedekah obat yaitu musyawarah, penentuan tempat, waktu serta menyiapkan bahan yang diperlukan dalam ritual.

Musyawarah adalah unsur sosial yang ada dalam banyak masyarakat pedesaan diseluruh dunia, keputusan yang diambil dalam suatu rapat tidak berdasarkan pendapat mayoritas, tetapi merupakan keputusan yang diambil secara bulat. Satu minggu sebelum diadakan tradisi Sedekah Obat masyarakat Desa Jermun mengadakan musyawarah di Balai Desa. Dalam musyawarah tersebut, kepala desa mengajak aparat, pemuka agama, pemuka adat dan berbagai elemen masyarakat masyarakat. Di dalam musyawarah membahas pelaksanaan Sedekah Obat, menentukan tempat upacara dilakukan, waktu upacara dilakukan, benda-benda dan alat-alat yang dipakai dalam upacara adat Sedekah Obat. Tradisi Sedekah Obat akan dilangsungkan apabila dalam suatu musyawarah sudah mencapai kesepakatan mengenai tempat pelaksanaan, waktu pelaksanaan, benda-benda dan alat upacara serta orangorang yang melakukan dan memimpin upacara. ${ }^{22}$

Sedangkan pihak-pihak yang terlibat dalam pelaksanaan upacara adat Sedekah Obat adalah seluruh masyarakat Desa Jermun, bukan saja Ketua Adat yang diperlukan melainkan Kepala Desa dan seluruh masyarakat tanpa terkecuali, dan disinilah terletak nilai-nilai kebersamaan di dalam masyarakat lantaran tradisi tersebut. Pada pelaksanaan Sedekah Obat untuk membaca doa dan pembukaan dipimpin oleh Ketua Adat. Pada hari pelaksanaan Sedekah Obat, seluruh masyarakat diperkenankan untuk hadir, kecuali yang berhalangan dan para kaum wanita yang sedang haid, hal ini dipercaya dikhawatirkan akan mempengaruhi nilai tradisi Sedekah Obat. Perlu diketahui bahwa, tempat pelaksanaan Sedekah Obat sudah ditentukan dari dahulu semenjak awal diadakannya Sedekah Obat yaitu dilaksanakan di rumah Ketua Adat. Sedangkan waktu pelaksanaan Sedekah Obat dilakukan 1 tahun sekali tepatnya pada bulan Muharam, untuk tanggal pelaksanaan tidak ditentukan, namun, sebelum pelaksaan tradisi Sedekah Obat, ketua adat akan mendapatkan sebuah mimpi dari (puyang)/moyang terdahulu sebagai tanda sudah waktunya akan dilaksanakannya tradisi

${ }^{22}$ Wawancara pribadi dengan Bapak Son (Warga Desa Jermun), Pada tanggal 26-09-2018. 
Sedekah Obat. ${ }^{23}$ Dalam hal ini selaras dengan penjelasan Koentjaraningrat dalam bukunya pengantar ilmu antropologi bahwa waktu pelaksanaan upacara tradisional biasanya dilaksanakan sebagai saat-saat yang penting atau gawat yang penuh dengan bahaya gaib. Hal ini timbul karena adanya bahaya misalnya wabah penyakit, bencana alam atau adanya peperangan. $^{24}$

Setelah diumumkan hari dilaksanakannnya upacara adat Sedekah Obat, masyarakat dan panitia menyiapkan peralatan yang akan dipakai dalam pelaksanaan upacara adat Sedekah Obat. Sebagai sebuah ritual turun-temurun dan mengandung nilai-nilai sakral, maka upacara ini membutuhkan peralatan dan bahan-bahan khusus. Bahan-bahan dan peralatan merupakan prasyarat sempurna tidaknya pelaksanaan upacara. Oleh karena itu, jika peralatan atau bahanbahannya tidak sesuai, maka tujuan dari upacara ini tidak akan tercapai. Bahan-bahan wajib yang mesti ada tersebut yaitu Beberapa potongan kayu Mamali yang dibakar dengan kemenyan, dalam hal ini, kayu mamali dan kemenyan dipercaya masyarakat di takuti oleh makhluk halus dan dapat menghindarkan masyarakat dari gangguan makhluk halus tersebut, disediakan pula kendi yang berisikan air ramuan yang sudah di doakan oleh ketua adat dengan campuran bunga 7 rupa yaitu; 1. Bunga mawar merah, 2. Mawar putih, 3. Bunga melati, 4. Bunga kenanga, 5. Bunga cempaka putih, 6. Bunga melati gambir, 7. dan bunga sedap malam. Kemudian di rumah ketua adat, para kaum perempuan sudah menyiapkan peralatan yang akan dipakai untuk memasak sebagai tahap akhir acara melaksanakan sedekah dawet ${ }^{25}$

\section{b. Tahap Pelaksanaan}

Tahap Pelaksanaan Upacara merupakan bagian inti dari tradisi Sedekah Obat ini karena berhasil atau tidaknya upacara sedekah ini terletak pada pelaksanaannya. Jika seluruh persiapan telah selesai di lakukan, maka dilangsungkan dengan acara pokok yaitu pelaksanaan Sedekah Obat. Adapun tahap pelaksanaan Sedekah Obat sebagai berikut: Masyarakat Desa Jermun mempersiapkan kayu mamali yang telah dibacakan doa oleh ketua adat dan telah dibersihkan lalu diletakkan di depan rumah ketua adat dengan membentuk lingkaran, fungsi dari kayu tersebut dipercaya agar saat proses pelaksanaan ritual tidak ada gangguan dari makhluk halus. Masyarakat diharuskan masuk dalam lingkaran tersebut, kemudian ketua adat keluar dari rumah dengan membawa wadah tembikar terbuat dari tanah liat yang berisikan beberapa potongan kayu mamali, potongan kayu mamali kemudian dibakar dengan kemenyan, dan sebuah kendi yang berisikan air ramuan bunga 7 rupa.

\footnotetext{
${ }^{23}$ Wawancara pribadi dengan Ibu Solbiah (Ketua Adat Desa Jermun), Pada tanggal 27-09-2018.

${ }^{24}$ Koentjaraningrat, Pengantar Ilmu Antropologi, hal. 254-255.

${ }^{25}$ Wawancara pribadi dengan Bapak Yustani (Warga Desa Jermun), Pada tanggal 26-09-2018.
} 
Sebelum dimulai, pembukaan ritual dibacakan oleh Ketua Adat dan dilangsungkan dengan pembacaan Surat Al-Fatihah sebanyak 3 kali. Pertama dikhususkan untuk Nabi Muhammad SAW kedua untuk warga desa yang telah meninggal, dan ketiga untuk Kaum Muslimin dan Muslimat, dalam hal inilah terkandung nilai-nilai agamis dari sebuah tradisi yang masih dilangsungkan oleh masyarakat desa Jermun. Setelah pembacaan tersebut selesai, mulailah ritual Sedekah Obat. Ketua adat masuk ke dalam lingkaran yang telah dipasangkan kayu mamali, sebelum memulai ritual, kendi yang telah berisikan air ramuan dibacakan surat Al-Fatihah lagi yang berfungsi ketika saat air ramuan dipercikkan ke setiap warga akan memberikan kesehatan dan supaya di jauhkan dari segala penyakit. Ketua adat berdiri setelah membaca surat Al-Fatihah seraya mengelilingi warga yang ada di dalam lingkaran tersebut dengan membawa kendi, lalu air yang ada di dalam kendi tersebut dipercikkan ke setiap warga desa yang ikut dalam proses ritual Sedekah Obat. Saat ketua adat mengelilingi dan memercikkan air kepada warga desa, ketua adat membacakan sebuah do'a sebagai berikut: ${ }^{26}$

Doa memakai bahasa daerah Desa Jermun oleh Ketua Adat Ibu Solbiah yaitu "Ya Allah kami ngadokan dekah Obat koni untuk minta keselamatan dari penyakit, nak beterimo kaseh atas nikmat kesehatan yang kau enjok ke kami, berilah kesehatan untuk msyarakat dusun ikon, enjok la keselamatan untuk masa yang akan datang, jauhkan dari penyakit-penyakit, sejahterakanlah dusun ikon, peliharokenyo dari hal yang tak dipengenkan, Aamiin". 27

Artinya: "Ya Allah kami melaksanakan Sedekah Obat ini untuk meminta keselamatan dari berbagai penyakit, kami ingin berterimakasih atas nikmat kesehatan yang telah engkau berikan kepada kami semua, berikanlah kesehatan untuk masyarakat desa ini, berilah keselamatan untuk masa yang akan datang, jauhkanlah dari berbagai penyakit-penyakit, berikanlah kesejahteraan desa ini, peliharalah kami dari hal yang tidak kami inginkan, Aamiin".

\footnotetext{
${ }^{26}$ Wawancara pribadi dengan Ibu Solbiah (Ketua Adat Desa Jermun), Pada tanggal 27-09-2018.

${ }^{27}$ Wawancara pribadi dengan Ibu Solbiah (Ketua Adat Desa Jermun), Pada tanggal 27-09-2018.
} 


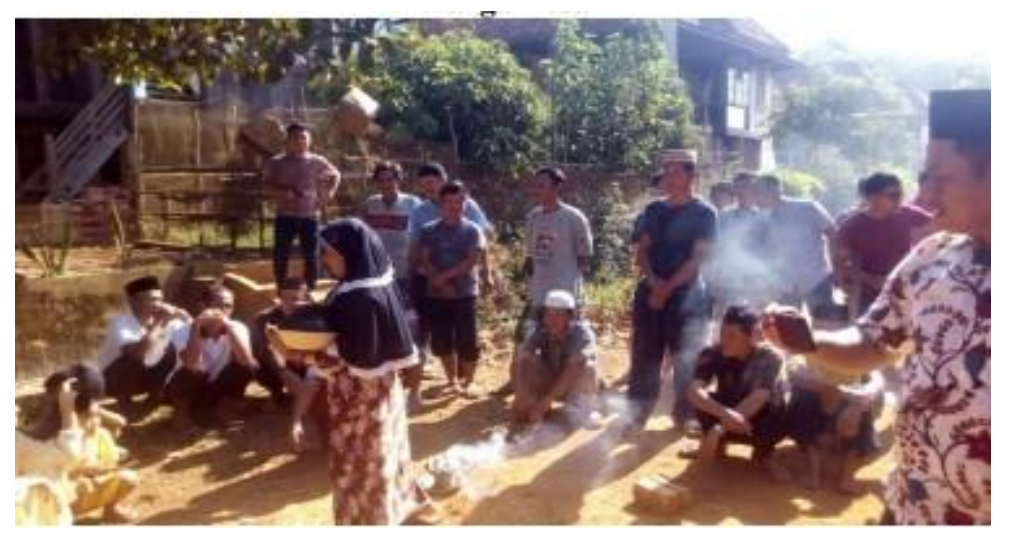

Foto: Ketua adat sedang memercikkan air kepada para para warga yang mengikuti pelaksanaan tradisi Sedekah Obat

\section{c. Tahap akhir.}

Setelah ritual Sedekah Obat selesai maka acara berikutnya adalah Sedekah Dawet sebagai acara terakhir daripada Tradisi ini. Dinamakan Sedekah Dawet karena di akhir acara ini masyarakat akan berkumpul untuk acara makan santap bersama di rumah ketua adat, dan makanan terkhusus yang telah disediakan adalah Dawet dan juga berbagai santapan lainnya. Sedekah Dawet ini digelar sebagai bentuk terimaksih dari ketua adat untuk masyarakat Desa Jermun yang telah bersedia membantu dalam proses tradisi Sedekah Obat dari awal hingga akhir. Kemudian keunikan dari tahap akhir dari tradisi ini adalah, satu persatu warga dibagikan sebuah benda berukuran $15 \mathrm{~cm}$, yang mereka sebut bulu kuning (bambu kuning) berukuran dipasang di atas pintu setiap warga, itu menandakan bahwa warga tersebut telah mengikuti ritual Sedekah Obat.

\section{Nilai-Nilai Yang Terkandung Dalam Tradisi Sedekah Obat}

Pada umumnya dalam tradisi di seluruh Indonesia tidak bisa dilepaskan daripada nilainilai yang terkandung yang berguna dan bermanfaat bagi kehidupan masyarakat setempat yang melaksanakan tradisi adat-istiadat tersebut, begitu pula dengan tradisi Sedekah Obat yang masih dilakukan oleh masyarakat Desa jermun memiliki nilai-nilai dan peranan penting di dalam element masyarakat.

Nilai merupakan objek keinginan yang mempunyai kualitas dan dapat menyebabkan seseorang mengambil sikap, baik setuju maupun memberi sifat-sifat tertentu. ${ }^{28}$ Nilai itu

${ }^{28}$ Louis Kattsof, Pengantar Filsafat (Yogyakarta: Tiara Wacana, 1987), hal. 332. 
bersifat ide dan abstrak, oleh karena itu tidak dapat disentuh oleh panca indra. Menurut Pringgodigdo nilai merupakan sifat-sifat (hal-hal) yang penting atau berguna bagi kemanusiaan, seperti nilai-nilai agama yang perlu kita indahkan. ${ }^{29}$

Dalam sistem kemasyarakatan, nilai memiliki peranan sangat penting. Baik dalam lingkungan keluarga maupun masyarakat, nilai-nilai dalam tradisi misalnya berguna bagi keluarga seperti nilai kasih sayang, nilai keindahan, keharmonisan dan lain-lain, serta di dalam masyarakat nilai juga berperan penting seperti nilai gotong royong, nilai kemaafan dan lain-lain. Dalam tradisi Sedekah Obat, terdapat nilai-nilai yang terkandung sebagai berikut:

1. Nilai Solidaritas, dilihat dari masih tingginya sikap tolong menolong dan rasa kepedulian dalam melestarikan budaya dalam bentuk bersama-sama mempersiapkan upacara adat tradisi Sedekah Obat. Selain itu juga sikap gotong royong ketika warga dalam melaksanaan tradisi Sedekah Obat.

2. Nilai Relegius/Agama, pada dasarnya merupakan suatu sikap seseorang (manusia) dalam usahanya secara bebas dan merdeka untuk menggapai Tuhan. Berkat kebebasan dan kemerdekaan yang dimiliki untuk mendekatkan diri dengan Tuhan, seorang dapat melakukan dengan berbagai macam cara. Dilihat dari tradisi Sedekah Obat di Desa Jermun, merupakan salah satu bentuk rasa syukur kepada Tuhan yang Maha Esa. Selain itu ritual keagamaan yang menyangkut dalam siklus hidup mulai dari kelahiran sampai dengan kematian masih ada dan harus dijalankan. ${ }^{30}$

3. Nilai silaturrahmi, dapat dilihat bahwa dengan adanya acara ini maka akan lebih menyambung silaturrahmi antar sesama warga masyarakat.

\section{E. KESIMPULAN}

Tradisi Sedekah Obat diadakan karena terjadi malapetaka yang menimpa masyarakat Desa Jermun. Akhirnya ketua adat pada zaman dahulu menyarankan untuk mengadakan Sedekah Obat, hingga tradisi ini tetap diwariskan pada generasi mendatang sampai saat ini. Hal yang terpenting dari pelaksanaan tradisi Sedekah Obat ini agar Desa Jermun selalu diberi keberkahan, kemudian diberikan kesehatan dan dijauhkan dari segala malapetaka. Inilah yang membuat masyarakat Desa Jermun setiap 1 tahun sekali mengadakan Sedekah Obat pada bulan Muharam (tahun baru Islam). Masyarakat yakin jika tidak dilaksanakan akan mendatangkan kekacauan dan malapetaka di Desa Jermun. Proses pelaksanaan Sedekah Obat

\footnotetext{
${ }^{29}$ Pringgodigdo and Hasan Sadily, Ensiklopedia Umum (Yogyakarta: Kanisius, 1973), hal. 749.

${ }^{30}$ Wawancara pribadi dengan Bapak Yustani (Warga Desa Jermun), Pada tanggal 26-09-2018.
} 
terdiri dari beberapa tahapan, yaitu tahap persiapan, pelaksanaan dan tahap akhir. Masyarakat Desa Jermun sangat menjunjung tinggi adat istiadat dan norma-norma yang berlaku. Diakadakannya Sedekah Obat dengan tujuan yang benar dan ini merupakan ungkapan rasa syukur kita sebagai manusia yang telah diberi kesehatan jasmani dan rohani, serta ungkapan rasa syukur kepada Allah SWT sebagai sang pencipta alam semesta. Nilai-nilai yang terkandung dalam tradisi Sedekah Obat sebagai berikut: 1, Nilai Solidaritas dan 2, Nilai Agama.

\section{DAFTAR PUSTAKA}

Ahmad Yunus, dkk.,. Arti dan Fungsi Upacara Daur Hidup pada Masyarakat Betawi. Jakarta: Depertemen Pendidikan dan Kebudayaan, 1993.

Berlian, Saudi. Mengenal Seni Budaya Ogan Komering Ilir. Palembang: Pemerintah Kabupaten Oki, 2003.

Harsojo. Pengantar Antropologi. Bandung: PT Rina Cipta, 1998.

Kattsof, Louis. Pengantar Filsafat. Yogyakarta: Tiara Wacana, 1987.

Koentjaraningrat. Kebudayaan, Mentalitet Dan Pembangunan. Jakarta: Gramedia, 1974.

—. Pengantar Antropologi II : Pokok-Pokok Etnografi. Jakarta: Rineka Cipta, 1997.

—. Pengantar Ilmu Antropologi. Jakarta: PT Rineka Cipta, 2003.

Krisnawati, Nila. "Makna Sedekah Pagi Dan Petang Bagi Masyarakat Suku Rambang." Skripsi, Institut Agama Islam Negeri Raden Fatah Palembang, 2003.

Nurhadi, Gendro. Pengkajian Nilai-nilai Luhur Budaya Spiritual Bangsa. Jakarta: Depdikbud, 1998.

Pringgodigdo, and Hasan Sadily. Ensiklopedia Umum. Yogyakarta: Kanisius, 1973.

Sabera Adib, Helen. Metodologi Penelitian. Palembang: Noer Fikri, 2016.

Sukmadinata, Nana Syaodih. Metode Penelitian Pendidikan. Bandung: Rosdakarya, 2005.

Sulaeman, M. Munandar. Ilmu Budaya Dasar. Bandung: Rafika Aitama, 2012. 
Tamaddun: Jurnal Kebudayaan dan Sastra Islam, Vol. 20 No. 2, 2020 |

—. Ilmu Sosial Dasar: Teori dan Konsep Ilmu Sosial. Bandung: Rafika Aditama, 2011.

Supriyadi. "Tradisi Sedekah Turun Benih Bagi Jama"eah Baratib Al-Qadiriyah Di Kelurahan Ngulak I Kecamatan Sanga Desa Kabupaten Musi Banyuasin (Tinjauan Historis).” Skripsi, Institut Agama Islam Negeri Raden Fatah Palembang, 2008.

Tim Penyusun. Pedoman Penulisan Skripsi Fakultas Adab dan Humaniora. Palembang: Fakultas Adab dan Humaniora Institut Agama Islam Negeri Raden Fatah Palembang, 2013.

Widiawati. "Unsur-Unsur Islam Dalam Upacara Adat Sedekah Pedusunan Di Desa Gaung Asam Kecamatan Lembak Kabupaten Muara Enim.” Skripsi, Institut Agama Islam Negeri Raden Fatah Palembang, 2012.

Wulandari. "Makna Simbol Krama Wali Dalam Adat Pernikahan Di Desa Karang Anyar Kecamatan Lawang Wetan Kabupaten Musi Banyuasin.” Skripsi, Institut Agama Islam Negeri Raden Fatah Palembang, 2003. 